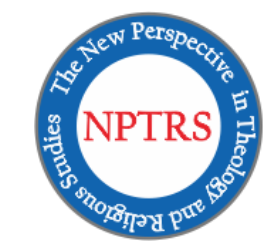

The New Perspective in Theology and Religious Studies

Vol. 1, No. 2 (2020):20-33

http://journalsttcipanas.ac.id/index.php/NPTRS/

p-ISSN 2722-9726, e-ISSN 2722-9718

Published by Cipanas Theological Seminary

\title{
Pandangan Kekuasaan dan Penderitaan Allah: Relevansinya terhadap Pemahaman Berteologi Masa Kini
}

\author{
Oinike Laia \\ Email: oinikelaia@gmail.com
}

\begin{abstract}
In general, people portray God as omnipotent, exalted, and infinite. Christian theology recognizes the important of these attributes. The classical Christian theology views the omnipotence in absolute terms and relates it to the idea of Divine Impassibility, an understanding that recognizes that God cannot suffer. When such a view is related to the concept of suffering God, a problem emerges. This article studies the aspects of the problem that arise from the two views regarding disharmony between sovereignty of God and suffering of God, by using descriptive qualitative methods. The result shows that there is a solution to the problem in a practical-Christological view that emphasizes the suffering of God from the viewpoint of the cross can serve as a framework. The study proposes the idea of Divine Passibility, that God can suffer as a form of love for humans. Thus, the view of sovereignty of God and God and suffering of God does not contradict each other but are interconnected. This study contributes to enriching the church members' understanding of God and Christ, especially in apologetics.
\end{abstract}

Keywords: Power, Sovereignty, Divine, Impassibility, suffering, Christology, Passibility.

\begin{abstract}
Abstrak
Pada umumnya orang menggambarkan Allah sebagai yangkuasa, mahamulia, dan tak terbatas. Dalam teologi Kristen pandangan serupa itu menduduki tempat yang signifikan. Teologi Kristen klasik menerima kemahakuasaan Allah secara mutlak dengan gagasan Impasibilitas Ilahi, pemahaman yang mengakui bahwa Allah tidak mungkin dapat menderita. Bila pandangan itu dihadapkan dengan pandangan mengenai Allah yang menderita, maka muncullah masalah. Tulisan ini merupakan hasil kajian terhadap permasalahan-permasalahan yang muncul dari kedua gagasan antara kemahakuasaan Allah dan penderitaan Allah, dengan menggunakan metode deskriptif kualitatif. Hasilnya adalah suatu solusi terhadap masalah di atas dan diperoleh dalam kerangka pikir praktis-kristologis, melihat penderitaan Allah dari sudut pandang salib. Studi ini mengajukan pandangan tentang pasibilitas ilahi, bahwa Allah bisa menderita sebagai wujud kasih-Nya kepada manusia. Dengan demikian, pandangan tentang kemahakuasaan dan
\end{abstract}


penderitaan Allah bukan kontradiksi, tetapi keduanya saling berhubungan. Temuan ini berguna untuk memperkaya pemahaman warga jemaat tentang Allah dan Kristus terutama dalam situasi menjawab pertanyaan orang lain.

Kata Kunci: Kekuasaan, Kedaulatan, Ilahi, Impasibiltas, penderitaan, Allah, Kristologi; Pasibilitas.

\section{Pendahuluan}

Gagasan mengenai kedaulatan Allah (the sovereignty of $G o d$ ) dan penderitaan Allah (the suffering of $\mathrm{God}$ ) mendapat tanggapan yang beragam dari para teolog Kristen. Gagasan mengenai kekuasaan Allah pada umumnya diterima oleh semua teolog Kristen tanpa penyangkalan. Bloesch mengemukakan bahwa di kalangan Kristen klasik, menerima atribut Allah yang berdauat, yang mahakuasa, dan maha kuat. Karena itu, mereka sangat menolak tentang gagasan penderitaan ilahi, karena penekanan mereka pada esensi Allah yang Maha Kuasa. ${ }^{1}$

Sebaliknya, gagasan tentang penderitaan Allah ditolak di kalangan teolog tertentu.

Richard Bauckham mengemukakan bahwa penolakan terhadap gagasan penderitaan ilahi banyak dipengaruhi oleh warisan teologi Kristen dari Yunani awal sampai pada abad ke-19. Mereka menekankan doktrin impasibilitas ilahi (divine impasibility), sebuah gagasan yang mengemukakan "ketidakmungkinan" Allah untuk menderita. Namun kemudian sekitar tahun 1890 aliran teolog Inggris yang sangat kuat melakukan pendekatan teologis yang beberbeda, yakni mulai menekankan mengenai doktrin penderitaan ilahi. Puncaknya pada tahun 1926 muncul minat untuk melakukan penelitian dari kalangan teolog Ingris, yakni JK Mozely. Ketika ia ditugaskan oleh Komisi Doktrin Uskup Agung (Archbishops' Doctrine Commission) pada tahun 1924 untuk melakukan penelitian mengenai impasibilitas Allah (the impassibility of God). Dalam penelitian tersebut Mozely mengemukakan ketertarikannya pada doktrin penderitaan Allah. Sejak itu, banyak teolog inggris melanjutkan tradisi tersebut, dan mengembangkan doktrin tentang penderitaan Allah (the suffering of God). ${ }^{2}$

Penerimaan terhadap gagasan penderitaan Allah terus berkembang sampai pada abad ke-20. Moltmann mengemukakan mengenai teologi salib yang berkaitan erat dengan pergerakannya kepada teologi pengharapan, yakni "kehadiran Allah dalam kebangkitan sebagai perwujudan janji-Nya dan kehadiran Allah di kayu salib sebagai perwujudan solidaritas-Nya dengan dunia dalam keterkutukan."3 Kemudian, minat terhadap pendalaman doktrin pendertiaan Allah mendapat perhatian, bahkan sampai ke Asia. Salah satu teolog pertama,

${ }^{1}$ Donald G. Bloesch, God the Almighty: Power, Wisdom, Holiness, Love (Illinois: IVP, 1995), 103.

2 Richard Bauckham, Only the Suffering God Can Help: Divine Passibility in Modern Theology, Themelios 9.3 (April 1984), 6: https://theologicalstudies.org.uk/article_god_bauckham.html. Diakses 22 Juni 2020 .

${ }^{3}$ Richard Bauckham, Teologi Mesianis: Menuju Teologi Mesianis Menurut Jurgen Moltmann (Jakarta: BPK Gunung Mulia, 1993), 71. 
teolog Lutheran dari Jepang bernama Kazoh Kitamori, ia menerbitkan buku yang terkenal berjudul, "Theology of the Pain of God." Jadi, para teolog yang menerima doktrin penderitaan Allah memahami bahwa penderitaan merupakan bagian penting dari solidaritas Allah terhadap manusia yang berdosa.

Penjelasan di atas menunjukkan bahwa terdapat perbedaan pandangan antara gagasan yang menekankan kemahakuasaan Allah dengan doktrin yang menerima gagasan penderitaan Allah yang akan dibahas dalam tulisan ini. Pembahasan pertama, menguraikan beberapa pandangan teolog mengenai gagasan kekuasaan Allah (the sovereignty of God), yang menekankan mengenai kemampuan Allah yang tak terbatas. Kedua, menguraikan gagasan pendertiaan Allah (the suffering of God) yakni, gagasan yang menerima bahwa Allah mungkin menderita. Selanjutnya, membahas ketegangan yang muncul, di satu pihak ada pandangan yang menekankan doktrin impasibilitas ilahi (divine impassibility), bahwa Allah yang tak terbatas tidak dapat menderita. Di pihak lain ada pandangan yang menolak pandangan tersebut, dan mengemukakan bahwa penderitaan Allah dapat terjadi karena kemahakuasaan-Nya. Selanjutnya pada bagian terakhir, mengemukakan hasil kajian sebagai solusi atas ketegangan pandangan tersebut dan relavansinya dalam pemahaman teologi Kristen masa kini.

\section{Kekuasaan Allah (The Sovereignty of God)}

Kata dasar yang digunakan untuk menjelaskan kekuasaan Allah dari bahasa Ibrani, yakni, "kabod," artinya kuasa atau kekuatan, keagungan, kemuliaan, martabat dan kemegahan. Menurut Samuel B. Hakh penggunaan kata "kabod" juga digunakan untuk menggambarkan keagungan manusia, tetapi dalam Alkitab, kabod cenderung digunakan untuk mengemukakan keagungan Allah. Beberapa contoh dikemukakan dalam Perjanjian Lama (PL), anara lain: ${ }^{5}$

a. Kabod digunakan untuk menunjukkan kuasa atau kekuatan Allah, seperti dikemukakan dalam Keluaran 14:4, 17-18, di mana kata kabod menunjuk pada kekuasaan Yahweh melebihi dari Firaun dan pasukannya, "dan terhadap Firaun dan seluruh pasukannya Aku akan menyatakan kemuliaan-Ku, sehingga orang Mesir mengetahui bahwa Akulah Tuhan".

b. Kabod digunakan untuk menggambarkan kemuliaan dan martabat Allah. Beberapa penekanan dalam PL menunjukkan bahwa Allah dihormati lebih dari yang lain, antara lain: Ia adalah Allah kemuliaan (Maz. 29:1-2), Raja kemuliaan (Maz. 24:7-10), kerajaan-Nya adalah kerajaan kemuliaan (Maz. 145:11-12).

c. Kata kabod juga diguanakan untuk mengambarkan kemuliaan dan kemegahan, yang menunjuk kepada Allah, antara lain: bait-Nya, kota-Nya atau perlengkapan kudus lainnya. Penggunaan kata ini umumnya berasal dari sumber P (Priest/imam-imam), di mana kabod

\footnotetext{
${ }^{4}$ Bauckham, Only the Suffering God, 7.

${ }^{5}$ Samuel B. Hakh, Melihat Kemuliaan Tuhan (Jakarta: UPI STT Jakarta, 2005), 13-16.
} 
berhubungan dengan penampakkan Allah dalam kemah pertemuan (Kel. 29:43, Im. 9:6, Bil. 14:10).

Dalam penjelasan di atas, Samuel B. Hakh cenderung menunjukkan bahwa kabod untuk menggambarkan kekuatan, kemuliaan dan kemegahan Allah. Klaus Hemmerle juga mengemukakan gagasan yang sama, ia menggambarkan kekuasaan Allah dengan kata power, dan dijelaskan dalam dua arti, yakni: (1) Pertama, power merupakan ide keagamaan yang utama dan sebagai kesadaran manusia tentang kekuasaan Allah yang dipahami dalam PL dan PB. (2) Kedua, power adalah sebuah sikap yang benar-benar berkuasa dan ini penting dalam hubungan sosial manusia yang paling mendasar. ${ }^{6}$ Dengan demikian Hakh dan Hemmerle melihat gagasan tentang kekuasaan dalam pengertian yang sama, yakni, diartikan sebagai kekuatan Allah, menunjuk kepada Allah yang mulia, Allah yang agung dan megah, dan Allah dalam kemuliaanNya, selalu berhubungan dengan manusia. ${ }^{7}$

Teolog lainnya yang membahas mengenai kekuasaan Allah adalah John M. Frame, dalam buku "The Doctrine of God." Ia mencatat bahwa semua nama Allah difokuskan pada derajat Allah yang mahakuasa, dan atribut ke-Tuhanan Allah menunjukkan keuniversalitas kendali-Nya atas segala sesuatu, baik dalam pemeliharaan atau penebusan. Seluruhnya menunjukkan kekuataan dan kekuasaan Allah yang sama. Salah satu contoh yang dikemukakan di ambil dariMazmur, "angkatlah kepalamu, hai pintu-pintu gerbang, dan terangkatkah kamu, hai pintu-pintu yang berabad-abad, supaya masuk Raja Kemuliaan! Siapakah itu Raja Kemuliaan?" “Tuhan, jaya dan perkasa, Tuhan, perkasa dalam peperangan!” (Maz. 24:7-8). Karena itu, pemahaman Frame tentang kekuasaan Allah berhubungan dengan kendali Allah atas segalanya. ${ }^{8}$ Maka untuk menjelaskan doktrin tentang kekuasaan Allah Frame menggunakan kata "power" (kuasa), dan kata omnipotence (kemahakuasaan). Ia juga merujuk pada dua gagasan yang berhubungan erat satu sama lain, yakni: Pertama, Allah dapat melakukan apa pun yang Dia sukai, seperti dikemukakan dalam Yohanes 23:13, bahwa, ".....Dia melakukan apa saja yang diinginkan-Nya," bahwa, "Dia melakukan apa yang dikehendaki-Nya" (Maz. 115:3), dan beberapa contoh lainnya dalam Alkitab. Kedua, gagasan tentang kemahakuasaan Allah menunjukkan bahwa tidak ada yang terlalu sulit bagi Tuhan. Hal ini menggambarkan apa yang Allah dapat lakukan dalam istilah universal, yakni, Ia bukan hanya dapat melakukan apa Dia kehendaki, tetapi tidak ada yang terlalu sulit bagi-Nya, seperti Firman Allah yang dikemukakan kepada Abraham, bahwa Sarah dapat memiliki seorang putra (lih. Kej. 18:13). ${ }^{9}$

\footnotetext{
${ }^{6}$ Klaus Hemmerle, Encyclopedia of Theology: the Concise Sacrament Mundi, ed. Karl Rahner, (New York: Crossroad, 1989), 1263-1265.

${ }^{7}$ Lih. Hakh, Melihat Kemuliaan Tuhan, 13-16. Hemmerle, Encyclopedia of Theology, 1263-1265.

${ }^{8}$ John M. Frame, The Doctrine of God: A theology of Lordship (Phillipsburg, New Jersey: P\&R Publishing, 2002), 513-514.

${ }^{9}$ Frame, The Doctrine of God, 515-516.
} 
Gagasan Frame mengenai kekuasan Allah dipengaruhi oleh Herman Bavink, di mana ia menggambarkan tentang Allah yang mahakuasa, Allah yang sempurna dan tanpa batas dengan menggunakan istilah "aseitas". Ia mendefinisikan aseitas Allah adalah sebagai diri sendiri atau milik-Nya sendiri, artinya sama dengan independence (kebebasan). Dibandingkan dengan Bavinck yang lebih menekankan bahwa Allah adalah berdiri sendiri (self-sufficient) dalam keberadaan-Nya, independence memiliki konotosi yang lebih luas, bahwa Allah mandiri dalam segala hal, dalam keberadaan-Nya, dalam atribut-Nya, dalam keputusan dan karya-karyaNya. ${ }^{10}$ Dengan demikian Frame dan Bavinck memilih menggunakan istilah Aseitas sebagai atribut untuk menunjukkan keberadaan Allah, sekaligus memperlihatkan bahwa Allah memiliki kekuasaan atas segala sesuatu. ${ }^{11}$

Gagasan yang sama mengenai kekuasaan Allah, juga dikemukakan oleh Donald G. Bloesch yang berpendapat bahwa Alkitab menggambarkan Allah yang memiliki kekuatan tak terbatas. Misalnya dalam pernyataan sukacita pemazmur, yang mengemukakan "Besarlah Tuhan kita, dan berlimpah kekekuatan, kebijaksanaan-Nya tak terhingga" (Maz. 147:5); dari Ayub yang mengaku, "Aku tahu, bahwa Engkau sanggup melakukan segala sesuatu, dan tidak ada tujuan Mu yang dapat digagalkan" (Ayb. 42:2). Dalam perspektif Alkitab, kekuasaan Allah dibuktikan dengan kasih-Nya yang tanpa batas, dan menjalankan kekuasaan-Nya untuk menebus dan membebaskan umat manusia yang hilang. Kekuasaan Allah tidak dapat dibatasi dan tidak dapat dipergunakan dengan sewenang-wenang, sebab kekuasaan-Nya meliputi kuasa kasih dalam penderitaan, dan Allah mengasihi umat-Nya dengan kasih yang kekal (lih. Yer. 31:3). Dari pemahaman ini, kemarahan Allah hanyalah bersifat sementara dan kasih-Nya berlangsung abadi (Yes. 54:7-8). ${ }^{12}$ Bloesch menyimpulkan, doktrin kekuasaan Allah adalah kebebasan kedaulatan Allah yang suci, penuh belas kasihan, bertindak untuk membela kebenaran-Nya, serta menghibur dan membebaskan. ${ }^{13}$

\section{Penderitaan Ilahi (The Suffering of God)}

Gagasan tentang penderitaan Allah mulai mendapat perhatian dalam teologi Kristen pada abad 19, yaitu dari kalangan teolog Inggris, salah satunya Mozely yang secara langsung mengatakan ketertarikannya pada doktrin penderitaan dan banyak teolog lainnya yang mendalami doktrin tersebut. Dalam tradisi Inggris, salib dipahami sebagai pusat dari sifat Allah dan penderitaan Kristus di kayu salib mengungkapkan bahwa Allah bisa menderita.

Penerimaan terhadap doktrin penderitaan Allah terus berkembang, dan menarik perhatian dari banyak teolog di berbagai tempat. Horace Bushnell, teolog dari Amerika juga memberikan perhatian yang mendalam terhadap doktrin penderitaan Allah. Ia mengemukakan

\footnotetext{
${ }^{10}$ Herman Bavinck, Doctrine of God (Grand Rapids: William B. Eerdmans, 1979), 144-145.

${ }^{11}$ Frame, The Doctrine of God, 600-601.

106.

${ }^{12}$ Donald Bloesch, God the Almighty: Power, Wisdom, Holiness, Love (Illinois: InterVasity Press, 1995),

${ }^{13}$ Bloesch, God the Almighty, 106-107.
} 
bahwa terlihat ada salib yang seolah berada jauh, dan yang terdengar hanyalah suara kasih dan kesabaran yang mendalam, mengalami penderitaan yang sama dengan manusia. Suara itu didengar oleh manusia dan itu berasal dari bukit suci Kalvari. ${ }^{14}$ Pendapat Bushnell juga mempengaruhi pandangan salah satu pengikutinya, CA Dismore, ia menyatakan bahwa, di hati Allah ada salib (penderitaan) dan salib itu telah ditanam di atas bukit hijau di luar Yerusalem. Salib itu tetap berdiam di hati Allah kepada setiap manusia yang berdosa dan menderita. ${ }^{15}$ Dengan demikian, Bushnell dan Dismore sama-sama menerima gagasan tentang pendertiaan Allah, yang digambarkan dengan kehadiran salib dan diperuntukkan untuk manusia, bahwa, Allah bisa menderita sebagai tanda kasih-Nya untuk manusia.

Penerimaan terhadap doktrin penderitaan ilahi semakin berkembang, terlebih di era teologi pembebasan atau di kalangan teolog kontemporer yang menemukan bahwa konsep penderitaan ilahi merupakan inti iman Kristen yang memiliki keunikan. ${ }^{16}$

Pada abad 20, gagasan mengenai penderitaan Allah mendapat perhatian yang serius dari Moltmann yang menguraikan teologi tentang penderitaan Ilahi dalam "Tuhan yang Tersalib, dalam Trinitas dan Kerajaan Allah." ${ }^{17}$ Secara spesifik, Moltmaan mengemukakan bahwa:

"Penderitaan Kristus adalah penderitaan Allah karena melaluinya Allah campur tangan dan mengalami sendiri atas nama kita, menyelamatkan kita pada titik di mana kita tidak dapat berdiri tetapi tenggelam dalam kehampaan: Allah bagi kita. Penderitaan Kristus adalah 'penderitaan Allah, karena akhirnya dari mereka segala ciptaan baru lahir: kita datang dari Allah. Solidaritas, kekuatan perwakilan dan kelahiran kembali adalah dimensi ilahi dalam penderitaan Kristus. Kristus ada dengan kita, Kristus adalah bagi kita, dan di dalam Kristus kita adalah ciptaan baru. Dalam arti apakah Allah cinta? Allah adalah kekuatan solidaritas, perwakilan, dan kekuatan regenerasi. ${ }^{18}$

Moltmann melihat salib sebagai tindakan solidaritas ilahi dengan mereka yang "ber-Tuhan dan terkutuk" dan Anak Allah benar-benar memasuki situasi mereka. ${ }^{19}$ Menurut Moltmann doktrin penderitaan Allah harus dipahami dari perspektif teologi salib. Dalam hal ini penyaliban Kristus adalah wujud nyata dari kasih Allah untuk umat-Nya. Dalam peristiwa salib Bapa meninggalkan Anak-Nya dan menyerahkan Dia sampai mati. Penyerahan Anak sampai mati ini adalah tindakan dari Bapa dan Anak, dan keduanya sama-sama menderita meskipun dengan cara yang berbeda. Keduanya menderita. Anak menderita karena ditinggalkan oleh Bapa saat

${ }^{14}$ Bauckham, Only the Suffering God, 11.

${ }^{15}$ Bauckham, ibid, 11.

${ }^{16}$ Ronald J. Feenstra (ed), The Passion of God: Divine Suffering in Contemporary Theology, by Warren McWilliams, publikasi online (Cambridge University, 9 September 2014), 60-61: https://www.cambridge.org/core/journals/horizons/article/. Diakses 25 Juni 2020.

17 Bauckham, Only the Suffering God, 7.

18 Jürgen Moltmann, The Way of Jesus Christ (Minneapolis: Fortress, 1993), 181.

${ }^{19}$ Bauckham, Only the Suffering God, Op.cit, 11. 
Ia meninggal dan Bapa menderita dalam kesedihan kematian Anak. Namun kesedihan Bapa sama pentingnya dengan kesedihan Anak. Karena itu, menurut Jurgen Moltmann untuk menjelaskan penderitaan ilahi, sangat penting untuk memiliki pemahaman yang lengkap tentang Allah Tritunggal, jika Yesus Kristus dipandang secara hakiki sebagai manusia dan Allah yang seutuhnya. ${ }^{20}$

Pandangan Moltmann tersebut senada dengan pandangan John M. Frame yang menuliskan:

"Konsili Chalcedon, yang mendefinisikan Kristologi ortodoks, mengatakan bahwa Yesus memiliki dua kodrat yang lengkap, ilahi dan manusia, bersatu dalam satu pribadi. Kita dapat mengatakan bahwa Yesus menderita dan mati di kayu salib "menurut sifat manusia," tetapi apa yang diderita bukan 'esensi,' tetapi pribadi Yesus. Dan pribadi Yesus tidak kurang dari yang kedua dari Tritunggal, yang telah diambil untuk sifat diriNya sebagai manusia. Pengalaman-Nya sebagai seorang manusia adalah pengalaman yang nyata, pengalaman Allah. ${ }^{21}$

Frame memberi gambaran bahwa penderitaan Allah dapat dipahami dari sudut pandang salib, bahwa penderitaan dialami dalam sifat manusia, tetapi penderitaan bukanlah natur pribadi Allah.

Kemudian, doktrin mengenai penderitaan Allah semakin mendapat perhatian penting di kalangan teolog Asia, seperti Kazoh Kitamori yang dari tradisi teologia Luther, dan kemudan diikuti oleh para teolog Asia lainnya yang menekankan penderitaan Ilahi. Lebih dari itu, teolog ini menempatkan penderitaan Allah sebagai bagian penting dari solitaritas kepada orang yang tertindas. ${ }^{22}$ Dalam buku Theology of the Pain of God, Kitamori menuliskan:

"Di sini keberadaan Tuhan sebagai fakta tidak harus dicari terpisah dari konsep Tuhan, tetapi berada dalam konsep itu sendiri. Dalam konsep "Allah" keberadaan-Nya sebagai fakta disertakan sebagai faktor konstituen penting dari konsep. Kesamaan, dalam konsep rasa sakit Allah, keberadaan historis Yesus, yang tampaknya bertentangan dengan konsep, termasuk sebagai faktor konstituen penting dari konsep. Sama seperti konsep "Allah" tidak dapat dibangun tanpa keberadaan-Nya sebagai fakta, sehingga konsep penderitaan Allah tidak dapat dibangun tanpa historisitas Yesus."23

${ }^{20}$ Moltmann, The Way of Jesus Christ, 181.

${ }^{21}$ John M. Frame, No Other God Response to Open Theism (Phillipsburg, New Jersey: P\&R Publishing, 2001), 187.

${ }^{22}$ Bauckham, Only the Suffering God, 7.

${ }^{23}$ Kazoh Kitamori, Theology of the Pain of God (Eugene Origon: Wipt \& Stock, 1965), 34. 
Kitamori memahami penderitaan Allah sebagai sebuah fakta dengan keberadaan Yesus yang menderita. Dengan demikian, para teolog yang menerima penderitaan Allah menekankan bahwa, "salib bukan hanya mengilustriasikan tentang penderitaan ilahi, tetapi merupakan peristiwa penentu bagi penderitaan ilahi, tanpa membatasi penderitaan Allah di atas salib." 24

Berdasarkan penjelasan mengenai penekanan Kitamori dan Moltmann tentang penderitaan Allah, gagasan tentang penderitaan Allah dapat dipahami dari sudut pandang salib yaitu sebagai peristiwa penderitaan internal untuk pribadi Allah Tritunggal sendiri, dan hal ini menentukan untuk doktrin Kristen tentang penderitaan Allah.

Namun, gagasan mengenai penderitaan Allah ini juga menimbulkan pertanyaan, yakni, berhubungan dengan keakuratan dari doktrin penderitaan Allah karena pada umumnya penerimaan terhadap doktrin penderitaan Allah dipengaruhi oleh situasi politik yang terjadi pada masa hidup teolog-teolog tersebut. Misalnya, dalam tradisi teologi Inggris, dampak dari Perang Dunia Pertama sangat besar sehingga mereka mengangkat masalah penderitaan untuk kepentingan bagi generasi dan pemulihan pada abad kesembilan belas. Demikian halnya dengan pandangan Kitamori tentang "The Pain of God" diterbitkan di Jepang segera setelah perang Hiroshima, ${ }^{25}$ sedangkan, teologi Moltmann berawal dari pengalamannya sebagai tawanan perang Jerman selama Perang dunia ke-II, yang dia sebut sebagai "concentration camp years". Pengalaman tersebut membuat ia menyatakan posisinya sebagai teolog Eropa yang mambahas krisis makna dan identitas modernitas yang sedang terjadi di gereja. ${ }^{26}$ Dalam keaadan inilah ia menemukakankan gagasannya mengenai doktrin penderitaan Allah berhubungan erat dengan salib. $^{27}$

Masalah hubungan penderitaan Allah dengan peristiwa salib tidak selesai dengan pemahaman di atas. Masih ada juga teolog yang membatasi peristiwa salib hanya sebagai penderitaan Anak. Misalnya pandangan yang menekankan penderitaan historis Yesus terkait dengan inkarnasi Kristologi yang diadopsi oleh HR Rashdall dan Frances Young, mereka berpendapat "penderitaan Yesus yang mengungkapkan penderitaan Allah, sebenarnya hanya diungkapkan dalam penderitaan manusia Yesus." ${ }^{28}$ Pandangan bahwa penderitaan salib terbatas untuk Anak umumnya dianut oleh teologi tradisional kuno "patripassian."29

\section{Menghubungkan Pandangan mengenai Kekuasaan dan Penderitaan Allah}

Sejauh ini dapat disimpulkan bahwa, kedua gagasan yang telah dipaparkan di atas, mengenai doktrin kekuasaan dan penderitaan Allah, sama-sama mendapat perhatian penting dalam tradisi teologi Kristen. Namun, terdapat persoalan apabila gagasan tentang doktrin

${ }^{24}$ Bauckham, Op. Cit, 11.

${ }^{25}$ Bauckham, Only the Suffering God, 7.

${ }^{26}$ Millicent C. Feske, "Christ and Suffering in Moltmann's Thought” dalam The Asbury Theological Journal, Vol. 55. No. 1 (Spring, 2000), 86: https://place.asburyseminary.edu/cgi/viewcontent. Diakses 27 Juni 2020.

${ }^{27}$ Bauckham, Teologi Mesianis, 65-68.

${ }^{28}$ Bauckham, Only the Suffering God, 11.

${ }^{29}$ Bauckham, Ibid, 11. 
kekuasaan Allah dikontraskan dengan doktrin penderitaan Allah, dan memunculkan perdebatan antara menolak atau menerima salah satunya. Salah satu pandangan yang secara ekstrim hanya menerima kekuasaan Allah diwariskan dari Yunani, dengan menekankan doktrin "Divine Impasibility" (Impasibilatas Ilahi). Di pihak lain, terdapat pandangan yang sangat menekankan tentang penderitaan Allah dan menolak gagasan Impasibilitas Ilahi.

\section{Doktrin Divine Apatheia/Impassibility dari Yunani}

Doktrin aphateia ilahi mempunyai pengertian yang sama dengan impasibilitas ilah, merupakan warisan dari teologi Kristen Yunani mula-mula. Dalam pamdangan itu, mereka memahami bahwa kekuasaan Allah tak terbatas, maka adalah kemustahilan jikalau Allah dapat menderita. Doktrin ini juga ditekankan dalam teologi Yahudi Helenistik yaitu dalam pandangan Philo, yang berpenapat bahwa Allah tidak dapat menderita. Doktrin ini didasarkan pada istilah apatheia (atau doktrin kemustahilan Allah menderita).

Bauckham menjelaskan bahwa gagasan tentang apatheia (Impassibility) ilahi, sebenarnya berhubungan erat dengan aspek-aspek lain dari pemahaman Yunani tentang Allah yang menempatkan penderitaan adalah hal yang terhubung dengan waktu, perubahan dan keperdulian. Semua fitur tersebut terjadi dalam dunia yang diciptakan. Sekaligus semua fitur tersebut bertolak belakang dengan pemahaman tentang keberadaan Allah sebagai eksistensi kekal dalam arti kurun waktu. Artinya, bahwa Dia adalah mutlak, sempurna sepenuhnya. Karena itu dalam doktrin Impasibilitas Ilahi memahami bahwa semua yang ada pada Allah adalah abadi. ${ }^{30}$ Dalam pengertian ini, Allah dipahami tidak bisa berubah, karena itu, jika Allah berubah itu merupakan hal buruk sebab, Allah adalah mandiri, Ia tidak dapat diubah atau mengubah diri-Nya, karena Allah adalah sempurna. Maka gagasan mengenai Allah dapat menderita dianggap sebagai gagasan penuh emosi yang tidak sesuai dengan sifat Allah.

Doktrin Impasibilitas Ilahi dari Yunani seperti dikemukakan di atas telah mempengaruhi pandangan Kristen klasik, yang kemudian lebih menekankan kekuasaan Allah yang tak terbatas, Allah melampaui atau kekuasaan absolut (potestas absoluta), Allah yang kuat. ${ }^{31}$ Bahkan dalam pandangan teologi Kristen klasik dikemukankan alasannya dengan menyertakan bukti dari pernyataan Alkitab, yang sangat kuat menekankan kemahakuasaan Allah. James S. Spiegel memaparkan beberapa pernyataan dalam Alkitab yang digunakan sebagai alasan kuat dalam doktrin impasibilitas, antara lain: (1) Pertama, Allah menguasai seluruh alam semesta (Kol. 1:16-17; Yes. 40:10); (2) Kedua, Allah berkuasa atas sejarah manusia dan pemimpin atas bangsa-bangsa (Yer. 18:6; Yeh. 26:1-6; Dan. 5:18-21); 3) Ketiga, Allah berkuasa terhadap setiap partikular pilihan manusia dan setiap perubahan-perubahan peristiwa manusia (Ams. 16:9; Kis. 1:24-26); (4) Keempat, Allah berkuasa atas gereja dan

\footnotetext{
${ }^{30}$ Bauckham, Ibid, 7.

${ }^{31}$ Bloesch, God the Almighty, 104.
} 
setiap kehidupan orang kristen (Ef. 1:4-5; Kis. 4:24-28); (5) Kelima, Allah berkuasa atas penderitaan dan kejahatan moral (Kel. 4:11; Yes. 45:6-7; Rat. 3:23-33). ${ }^{32}$

Berdasarkan penjelasan di atas menunjukkan bahwa dalam doktrin impasibilitas, gagasan mengenai penderitaan Allah merupakan kemusttahilan, sebab, pnenderitaan dianggap sebagai tanda kelemahan, dan hal itu tidak sesuai dengan Allah.

\section{Penolakan terhadap Doktrin Divine Impassibility}

Salah satu teolog yang menolak impasibilitas ilahi dalam menjelaskan doktrin tentang kekuasaan Allah adalah Karl Barth. Ia mengemukakan bahwa Alkitab justru tidak melulu tertarik untuk membahas mengenai kekuasaan Allah atas segala sesuatu atau kekuatan yang menciptakan, dan penggerak dunia, sesuai dengan doktrin impasibilitas. Barth menunjukkan gagasan tentang kesediaan Allah (readiness of God) yang tak terbatas untuk menebus dan memulihkan. Karena itu, kepercayaan Barth pada kekuasaan Allah yang tidak terbatas digambarkan dalam dua istilah "His power to will" dan "His power not to will" (kemauan kekuasaan-Nya dan ketidakmauan akan kuasa-Nya). Karena itu, dalam teologi Barth, ia menekankan bahwa Allah tetap sebagai Allah yang Mahakuasa, ${ }^{33}$ dan dlam pernyataan ini ditunjukkan pula kedauatan-Nya. Karena kedaulatan-Nya itu, Allah bebas berindak untuk menebus dan memulihkan umat manusia dengan cara yang ditentukan oleh Allah sendiri. Dengan demikian Allah bisa menderita dengan keputusan Allah sendiri yang menanggung penderitaan manusia dalam diriNya sendiri.

Teolog lainnya adalah Otto Weber seorang teolog Jerman yang menolak gagasan kekuasaan mutlak seperti ditekankan dalam doktrin impasibilitas dari teologi Yunani dan teologi Kristen klasik. Otto Weber berpendapat:

"Jika kemahakuasaan Allah tidak lain dari mempertahankan 'kekuasaan', 'will' dan 'pengetahuan' Allah, maka itu bukan merupakan atribut Allah dalam kebebasan-Nya, tetapi lebih kepada memaksa Allah ke dalam sistem hukum yang diperlukan seperti yang kita lihat atau yang inginkan. Dan tidak lain dari ekspresi apa yang Allah 'wasiatkan', dasarnya, 'must' will atau have wanted to will (harus atau kemauan)."34

Pandangan yang sama juga ditekankan oleh Dietrich Bonhoeffer, seperti dikutip oleh Bloesch, ia mengemukakan tentang perlunya untuk memahami Allah dalam hal ketidakberdayaan-Nya (powerlessness) daripada kemahakuasaan (almightiness). Karena itu, Bonhoeffer menerima bahwa gagasan kekuasaan Allah bukan sebagai pertentangan tetapi paradoks dari kekuatan ketidakberdayaan karena kasih-Nya. Secara spesifik, Bonhoeffer

32 James S. Spiegel, "Does God Take Risk" dalam God Under Fire, ed. Douglas S. Huffman dan Eric L. Johnson (Grand Rapids: Zondervan, 2002), 200-201.

${ }^{33}$ Karl Barth, Church Dogmatics, Vol. II.1 (Edinburgh: T \& T, 1957), 602.

${ }^{34}$ Bloesch, God the Almighty, 105. Lih. Otto Weber, Foundations of Dogmatics, trans. Darrell L. Guder (Grand Rapids: Eerdmans) 1:444. 
mengemuakan, "God allows himself to be edged out of the world and on the cross. God is weak and powerless in the world, and that is exactly the way, the only way, in which he can be with us and help us. ${ }^{135}$

Penjelasan di atas menunjukkan adanya perbedaan pendekatan pada penekanan doktrin Allah Mahakuasa, Pandangan Yunani yang mempengaruhi teologi kristen klasik lebih menekankan kepada Allah yang tidak bisa menderita dalam pengertian bahwa Allah tidak mungkin memiliki kelemahan. Menurut mereka Allah yang menderita adalah tanda kelemahan dan tidak sesuai untuk Allah yang memiliki kekuasaan yang absolut. Sementara beberapa teolog yang menolak pandangan itu menekankan kepada kemahakuasaan Allah namun Allah tetap terlibat untuk kebaikan ciptaan-Nya dan Allah tidak mengabaikan kebebasan manusia. Persoalannya, bagaimana menjembatani kedua pandangan yang bertentangan atau berbeda penekanan tersebut di atas.

\section{Solusi dan Relevansi dalam Pemahaman Berteologi pada Masa Kini}

Sejauh ini sudah jelas bahwa, gagasan mengenai kekuasaan ilahi diterima sebagai atribut Allah yang absolut oleh semua kalangan kristen, yang mengemukakan tentang Allah yang Maha kuasa, Maha mulia, dan tak terbatas. Namun, permasalahan muncul ketika gagasan tersebut dikontraskan dengan gagasan mengenai penderitaan Allah, yakni, doktrin tentang Impasibilitas Ilahi, yang berpendapat bahwa Allah tidak mungkin dapat menderita. Karena itu, gagasan Impasibilitas Ilahi juga mendapat penolakan dari banyak teolog seperti telah dikemukakan di atas. Maka untuk menyelesaiakan ketegangan tersebut, akan diuraikan solusi terhadap persoalan yang muncul, berdasarkan hasil pengamatan terhadap beberapa pandangan yang menolak dan menghasilkan rujukan untuk solusi.

Salah satu gagasan yang muncul sebagai solusi adalah dengan memunculkan doktrin Divine Passibility (Pasibilitas Ilahi) yang telah muncul dari teologi Inggris. Hasilnya, muncul penerimaan bahwa Allah bisa menderita, sebagai wujud kasih dan keperduliaan Allah terhadap pederitaan manusia.

Pandangan yang menerima doktrin Pasibilitas Ilahi (bahwa Allah bisa menderita), pada umumnya berhubungan erat dengan pendekatan praktikal, yakni bahwa Allah bisa menderita karena kebebasan Allah dalam kasih-Nya, dan relasi Allah dengan manusia dimana keduanya terjalin dalam diri Kristus yang berada di kayu salib. Dalam diri Kristus, ada natur Kristus sebagai manusia sekaligus ada natur Allah di dalamnya. Hal ini merupakan gambaran yang nyata bahwa Allah turut "merasakan" penderitaan manusia dan Kristus datang untuk menggantikan mereka.

Beberapa teolog yang menerima gagasan penderitaan Allah, yang telah diuraikan di atas, seperti Karl Barh, Otto Weber, Jürgen Moltman, dan teolog lainnya, didasarkan pada

35 “Allah mengijinkan diri-Nya menjadi terdorong ke sisihkan di tepi dunia dan ke atas kayu salib. Allah adalah lemah dan tak berdaya di dalam dunia, dan itu merupakan satu-satunya cara di mana Allah dapat bersama kita membantu kita." Bloesch, Ibid, 105. 
pendekatan "practical-Christological," (praktis-kristologis), bahwa penderitaan Allah dipahami dari sudut pandang salib, di mana pendertiaan Kristus merupakan wujud kasih Allah kepada manusia.

Penekanan yang sama juga dikemukakan oleh John Piper yang mengemukakan bahwa, "kedatangan Yesus Kristus untuk menderita dan mati adalah manifestasi tertinggi dari kesadaran akan kemuliaan anugerah Allah, atau untuk mengatakan dengan sedikit berbeda kematian Kristus dalam penderitaan yang tertinggi merupakan pameran kemuliaan anugerah Allah yang paling tinggi, paling jelas, dan paling meyakinkan." ${ }^{36}$ Dalam pernyataan ini Piper menunjukkan bahwa doktrin tentang penderitaan ilahi, tidak mengurangi kemahakuasaan Allah, karena penderitaan Allah yang diimplementasikan dalam penderitaan Kristus merupakan pertunjukan dari kemuliaan dan kemahakuasaan Allah.

Pandangan lainnya yang menggunakan pendekatan practical-Christological adalah Dan McCartney, yang beranggapan bahwa penderitaan Kristus di kayu salib bukan sekedar untuk solidaritas kepada manusia, tetapi penderitaan Kristus adalah untuk karya keselamatan. McCartney mengemukakan;

"Di kayu salib Yesus berdiri di tempat umatnya dengan menjalani penderitaan mereka sebagai orang berdosa, dan kemudian dalam kebangkitan mewujudkan peninggian bahwa ia sebagai penderita benar layak. Kata-kata Yesus harus mempengaruhi cara kita memandang penderitaan. Penderitaan-penderitaan salib (dan kebangkitan) Tuhan dan Juruselamat Yesus Kristus adalah peristiwa paling penting dalam sejarah. Tuhan tidak membebaskan diri dari penderitaan, tetapi Ia masuk sepenuhnya dalam pribadi AnakNya. Dan, misterius, penderitaan Allah yang menjelma menyelesaikan keselamatan kita."37

Pernyataan di atas menunjukkan bahwa McCartney melihat gagasan tentang penderitaan Allah bukan hanya dari sudut pandang doktrin Kristen, melainkan dari sudut pandang penderitaan salib, untuk keselamatan manusia atau soteriologi.

Berdasarkan beberapa uraian yang telah dikemukakan di atas, dapat disimpulkan bahwa bahwa gagasan tentang kekuasaan Allah bukan sebagai kontradiksi dari gagasan tentang penderitaan Allah. Pendekatan praktis-kristologi memberikan solusi untuk melihat keduanya sebagai gagasan yang saling berhubungan, dengan gagasan yang dimunculkan oleh beberap teolog modern, yakni doktrin Divine Passibility (Pasibilitas Ilahi), yakni, gagasan yang mengakui bahwa Allah bisa menderita untuk menyatakan kasih-Nya kepada manusia. Kasih Allah terwujud melalui penderitaan Kristus di atas salib, di mana melalui salib Allah mengambil hukuman (penderitaan) yang harusnya ditanggung oleh manusia. Meskipun harus diakui bahwa

\footnotetext{
${ }^{36}$ John Piper, Justin Taylor, Suffering and Sovereignty of God (Illinois: Crossway Books, 2006), 81-82.

${ }^{37}$ Dan G. McCartney, The Suffering and the Goodness of God in the Gospels, dalam, Suffering and The Goodness of God, Ed. Christhoper W. Morgan dan Robert A. Paterson (Illinois: Crossway, 2008), 93.
} 
setiap teolog tidak lepas dari pengaruh pengalaman pada konteks zamannya. Namun penerimaan terhadap doktrin penderitaan ilahi yang dihubungkan dengan penderitaan Kristus (salib), dapat mendorong teolog Kristen pada masa kini untuk mengembangkan teologi tentang Allah yang hadir untuk menjawab persoalan manusia di sepanjang zaman.

Gagasan yang telah dikemukakan oleh Moltmann, terkait dengan subjek teologisnya yang dominan tentang Kristus dan Penderitaan, sebenarnya dapat membuka pintu transformasi, sehingga terciptanya pintu wacana teologis Kristen tentang salib, sebagai harapan dan iman. Demikian juga dalam penekanan John Piper, yang melihat penderitaan dan kedaulatan Allah untuk menunjukkan kebesaran dan kemuliaan anugerah Allah.

Dengan demikian itu, doktrin kekuasaan Allah dan penderitaan Allah tidak perlu dipandang sebagai gagasan yang bertentangan, tetapi merupakan paradoks yang saling berkaitan, namun sebagai wujud kasih Allah terhadap umat manusia. Dengan demikian, dalam konteks berteologi di masa kini, secara khusus ketika dunia sedang berada dalam keaadan yang sulit, kacau dan menderita, maka teologi Kristen mampu melihat bahwa Allah yang berkuasa atas segalanya, dan Allah menunjukkan kebesaran-Nya dalam bentuk kasih yang ikut berada di tengah dan merasakan penderitaan manusia.

\section{Kesimpulan}

Doktrin tentang kekuasaan dan penderitaan Allah merupakan gagasan yang sama-sama diterima di kalangan teologi Kristen. Namun, terdapat beberapa perbedaan penekanan sehingga menimbulkan kontradiksi di antara kedua gagasan tersebut. Perbedaan yang sangat kontras ditunjukkan dengan pandangan yang menekankan Divine Impassibility (Impasibilitas Ilahi), yang menerima atribut Allah sebagai yang Mahakuasa dan tanpa batas sehingga, tidak mungkin Allah tang tak terbatas menderita. Dasar pandanga itu adalah penderitaan dianggap sebagai tanda kelemahan, dan hal itu tidak sesuai dengan keberadaan Allah yang Mahakuasa.

Sebaliknya gagasan tentang Divine Passibility (Pasibilitas Ilahi), merupakan teologi yang terbuka dan menerima bahwa Allah bisa menderita, tetapi hal itu harus dipahami dari sudut pandang salib, yakni, penderitaan Kristus merupakan penderitaan Allah sebagai wujud kasih Allah untuk membebaskan umat manusia dari penderitaan.

Sebagai solusi, telah dipaparkan gagasan yang dapat digunakan sebagai alternatif berteologi untuk masa kini, bahwa kekuasaan dan penderitaan Allah bukanlah gagasan yang bertentangan, tetapi keduanya paradoks dan saling berkatitan yaitu, dalam penderitaan Allah, yang diwujudkan dalam penderitaan Yesus, dilibatkan kemanusiaan dan keilahian-Nya, dalam arti bahwa Ia adalah sepenuhnya Allah dan manusia yang berinkarnasi; bahwa Allah menderita dan mati bagi manusia dalam Yesus Kristus adalah pernyataan benar dan akurat. Namun dalam sudut pandang doktrin harus ditegaskan bahwa sifat ilahi Yesus tidak secara khusus menderita dan mati dari diri-Nya sendiri, tetapi hanya menunjukkan pada kesatuan pribadi Allah dan manusia. 
Salah satu pendekatan yang membantu untuk melihat keterkaitan antara gagasan tentang kekuasaan dan penderitaan Allah adalah dengan pendekatan practical-Christiological (Kristologis-praktika), yang merupakan implikasi dari doktrin Allah Tritunggal. Pendekatan ini memberikan pemahamaman kepada umat percaya bahwa dalam kemahakuasaan Allah, Ia dapat memilih untuk menderita, sebagai wujud solidaritas dan kasih-Nya yang sempurna untuk membebaskan, dan menyelamatkan umat manusia dari dosa.

\section{Daftar Pustaka}

Barth, Karl., Church Dogmatics, Vol. II. 1. Edinburgh: T \& T, 1957.

Bauckham, Richard., Teologi Mesianis: Menuju Teologi Mesianis Menurut Jurgen Moltmann. Jakarta: BPK Gunung Mulia, 1993.

., Only the Suffering God Can Help: Divine Passibility in Modern Theology, Themelios 9.3 (April 1984):

https://theologicalstudies.org.uk/article_god_bauckham.html. Diakses 22 Juni 2020.

Bavink, Herman., Doctrine of God. Carlise, Grand Rapids: William B. Eerdmans, 1979.

Bloesch, Donald G., God the Almighty: Power, Wisdom, Holiness, Love. Illinois: IVP, 1995.

Feske, Millicent C., "Christ and Suffering in Moltmann's Thought" dalam The Asbury Theological Journal, Vol. 55. No. 1 (Spring, 2000), 86: https://place.asburyseminary.edu/cgi/viewcontent. Diakses 27 Juni 2020.

Frame, John M., The Doctrine of God: A theology of Lordship. Phillipsburg, New Jersey: P\&R Publishing, 2002.

., No Other God Response to Open Theism. Phillipsburg, New Jersey: P\&R Publishing, 2001.

Frestra, Ronald J. (ed)., The Passion of God: Divine Suffering in Contemporary Theology, by Warren McWilliams, publikasi online (Cambridge University, 9 September 2014), 60 61: https://www.cambridge.org/core/journals/horizons/article/. Diakses 25 Juni 2020.

Hakh, Samuel B., Melihat Kemuliaan Tuhan. Jakarta: UPI STT Jakarta, 2005.

Hemmerle, Klaus., Encyclopedia of Theology: the Concise Sacrament Mundi, ed. Karl Rahner. New York: Crossroad, 1989.

Kitamori, Kazoh., Theology of the Pain of God. Eugene Origon: Wipt \& Stock, 1965.

McCartney, Dan G., "The Suffering and the Goodness of God in the Gospels," dalam, Suffering and The Goodness of God, Ed. Christhoper W. Morgan dan Robert A. Paterson. Illinois: Crossway, 2008.

Moltmann, Jürgen., The Way of Jesus Christ. Minneapolis: Fortress, 1993.

Piper, John dan Justin Taylor, Suffering and Sovereignty of God. Illinois: Crossway Books, 2006.

Spiegel, James S., "Does God Take Risk” dalam God Under Fire, ed. Douglas S. Huffman dan Eric L. Johnson. Grand Rapids: Zondervan, 2002. 